\title{
A Problem-Based Learning (PBL) and Teaching Model using a Cloud-Based Constructivist Learning Environment to Enhance Thai Undergraduate Creative Thinking and Digital Media Skills
}

\author{
https://doi.org/10.3991/ijim.v15i22.24963 \\ Parawee Srikan, Paitoon Pimdee ${ }^{(凶)}$, Punnee Leekitchwatana, Akan Narabin \\ King Mongkut's Institute of Technology Ladkrabang (KMITL), Bangkok, Thailand \\ paitoon.pi@kmitl.ac.th
}

\begin{abstract}
The objective of this research was to develop a Problem-Based Learning (PBL) Model which used a cloud-based constructivist learning environment to enhance Thai undergraduate creative thinking and digital media skills. Initially using a mixed-methods approach, a five-step model was conceptualized. Thereafter, a panel of five academic experts gave input into the model's design from which the model was expanded to include six related learning environments. The instrument used in the research was a problem-based assessment form. Data collection was carried out utilizing group chats and analyzed using descriptive statistics including the mean and standard deviation. The results of the study revealed that the initial model contained five steps including (1) problem identification, (2) problem analysis, (3) research, (4) presentations, and (5) summary and evaluation, which is integrated into the model's additional six learning environment elements. These six learning environments were (1) problem-based, (2) resources, (3) cognitive tools, (4) collaboration, (5) scaffolding, and finally, (6) coaching. When applying the proposed model and related environments, there was a consensus from the experts that the model had excellent suitability and can be used as a model for teaching and learning at the bachelor's degree level.
\end{abstract}

Keywords—computational thinking, critical thinking, internet, Thailand

\section{Introduction}

Today, student university education is being transformed due to digital technologies being integrated into the classroom environment [1], where the importance of each teacher's learning activities is of crucial importance in assisting students in building their comprehension and learning stimulation. Also, student cooperative classroom activities are the driving force for self-knowledge creation, which has its roots in constructivist-inspired thinking [2], where knowledge is acquired through content involvement instead of imitation or repetition [3]. This is consistent with early research from Papert on the concept of computational thinking (CT) in which he considered CT to be a result of his constructionist educational approach, where affective and social 
dimensions are as crucial as the technical content of the lesson [4]. Papert's CT also stressed the computer's importance as a powerful meta-tool for "making the abstract concrete" as well as the assertion that these CT skills were transferable to other disciplines. Therefore, CT promotion today is potentially possible through the use of various digitally-based platforms and environments such as flipped classrooms and blended e-learning models, using the integration of online learning and digital technology devices such as smartphones, tablets, and learning management systems (LMSs) such as Moodle and Schoology [5]-[8] and the Internet of Things (IoT) [9].

Therefore, the use of digitally based learning platforms and models such as flipped classrooms and blended learning using the Internet cloud has become an educator's way of embracing $21 \mathrm{st}$ - Century technological digital innovation in which student-centered assigned lectures outside of class is now possible [9], [10]-[12]. These new digitally based, Internet cloud-hosted classroom environments also fuel the need for information, communications, and technology (ICT) development mandated under ICT objectives laid out by Thailand's 12th National Economic and Social Development Plan [13] and precepts outlined under Thailand's 4.0 goals for digitally based knowledge-workers.

When combined with student preparation outside the classroom, in-classroom analytical problem-solving activities, and complex problem-based learning (PBL) processes based on computer science techniques, the authors believe that creative thinking and critical thinking skills can be increased. However, educators must be willing to encourage learners to engage during learning sessions and assist in the process of solving teacher-led problem-based learning (PBL) exercises [14]. This can then lead to advanced thinking process development, learning enjoyment, and higher-order thinking skills (HOTS). It has also been added that that HOTS uses concept formation, critical thinking, creativity and brainstorming, problem-solving, mental representation, rule use, reasoning, and thinking logically [15]. This then can lead to a student's ability to understand complex problems by logically connecting different sets of information, which can then provide various perspectives on problem-solving. Therefore, 21 st Century educators need to integrate ICT skills, digital literacy skills, knowledge, and attitudes [6], [16] into their IoT classrooms [17].

Furthermore, research has contended that there is a growing need to integrate constructivist environments into pedagogical practices [18] in which students are supported in building and reflecting on their knowledge from previous critical thinking teacher-guided exercises. Therefore, in this new and evolving world of digital-based devices connected to cloud-based learning platforms and resources, collaboration and constructivism become tools in new knowledge creation [19].

Therefore, in learning activities, learners are independent and have their own goals to create a body of knowledge on their own and apply this knowledge to create innovation within society [20]. Moreover, creativity is a special process of the human brain, which makes it possible to see new possibilities and alternatives. Creativity and critical thinking skills also allow members of society to face their fears, hardships and solve challenging problems. Moreover, change is accelerating and online education is a way to meet this change head-on. Also, in a Covid-19 pandemic world, education has been forced to move online. However, the good news according to the United Nations 
Children's Fund (UNICEF) in a 2017 report is that the most Internet-connected age group in the world is from 15 to 24 , with $71 \%$ being connected online as compared to the global average of $48 \%$ [21]. Therefore, mobile digital devices connected to cloudbased platforms can create opportunities for collaboration and transform the way we live, relax, spend our free time, and even have fun. Creative innovation is also being used to improve the quality of life in preparing young people to enter the real world, who can deal with difficulties, challenges, and solve real-world problems.

\section{Supporting literature}

The following sections are a brief overview in support of the authors' development of the study's proposed conceptual learning model.

\subsection{Problem-based learning (PBL)}

In the process of problem-solving, educators make use of learning models to actively involve and stimulate student thinking skills [22], [23]. In recent years more and more teachers have integrated PBL concepts into their classrooms as PBL actively involves students in investigating and participating with authentic and meaningful problems whose result is the creation of knowledge and concepts from each discipline studied [24]. Other researchers have also reported on the positive outcomes (motivation and digital literacy increases) when PBL is integrated with some form of online learning [14], [25], [26]. Moreover, when a blended-PBL classroom is created, effectiveness is even further enhanced over conventional PBLs [27] and is effective in increasing the student's learning activities motivation [28]. Finally, numerous studies have reported that when digital devices are integrated with PBL activities, critical thinking and creativity skills are increased [29].

Therefore, PBL aims to manage learning in such a way that learners have the most opportunity to learn by themselves through study, research, experimentation, practice, thinking, problem-solving, and creativity [30]. Also, PBL is an appropriate teaching method for developing learners in the 21 st Century because it is a teaching method that uses problems or situations as a starting point for learning and the seeking of knowledge [31], which then can potentially develop problem-solving skills, self-learning and teamwork [32].

In this environment, students can create new knowledge by applying real-world problems as a learning context to develop skills in critical thinking and problem solving [30], as well as gaining knowledge based on science in the field of study. Since PBL is a teaching technique that encourages students to practice and solve problems on their own, student skills in logical thinking and critical thinking, analytical thinking, synthetic thinking, and creative thinking are enhanced. Other studies have also suggested that PBL learning enhances learner hypothesis and reasoning skills, self-study skill development, and teamwork and collaboration effectiveness [32]. Therefore 'chalk and talk' dies and classroom environments become livelier, promoting cooperation and collaboration between departments or agencies. 


\subsection{Cloud-based constructivist learning environment (CBCLE)}

Learning based on constructivist theory is a process that takes place within the learner with each individual creating knowledge from the relationship between what they see and their past knowledge and previous understandings [24]. In this process, individuals try to use their understanding of events and phenomena they see to create or adjust their existing cognitive structures to the new environment.

Within the digital world, it has been suggested that a well-designed mobile game that requires player agency and meaning is an excellent example of constructivist learning [33]-[35]. Moreover, to achieve a balance between one's self and the learning process, constructivist theory encourages children to do activities according to their interests, while taking into account the important basic elements of their interest, play, experimentation, and cooperation. Also, constructivist or student-centered learning asks students questions, after which the learners are divided into small groups who work together to discover one or more solutions [36]. Also, the relationship between the teacher and the learner should be cooperative rather than compulsory or control-driven [37].

Also, although digital learning tools and learning applications can run on a single computer or a network of computers not attached to the Internet, this is becoming rarer as educational institutions equip their faculties to assess applications (apps) outside their physical environment. Today, a frequently used term to describe the processes, tools, and locations of these apps is the word 'cloud' which is nothing more than a metaphor for the Internet. Although it can be debated as to the term's origination, some might suggest it comes from the design element used for the Internet in network design software (a cloud) or maybe even further back as the word used by Telco operators to describe their network facilities outside their switch rooms. Either way, today the 'cloud' is a critical element in serving up countless educational tools from around the world.

When educators discuss flipped or blended-learning classrooms or Khan Academy, it is necessary to talk about the application servers supporting the learning environment which run in the cloud such as Moodle ${ }^{\circledR}$, Schoology $^{\circledR}$, or the vast array of Google apps such as Google for Education ${ }^{\circledR}$. It is also impossible to talk about Social Media such as Facebook ${ }^{\circledR}$ or Line ${ }^{\circledR}$ without also talking about access to their servers in the cloud.

Therefore, the adoption of cloud technology as a teaching tool is very important in promoting new ideas for learners. One great advantage often mentioned in Flipped classrooms is the idea that education can take place anytime and anywhere. Beyond the obvious advantage of having an application hosted by a service provider that has the infrastructure to assure maximum connectivity and bandwidth around the clock, there are also other significant cloud computing advantages such as unlimited network storage, backup, redundancy, ever-increasing processing power, management, and security. Significant ICT and personnel costs are also offloaded in most cases from the institution to the vendor in the cloud. This by itself is a powerful motivational aspect for using cloud-based applications.

\subsection{Creative thinking}

In the age of Information, creativity has increasingly risen in value as a crucial capability [38] which has also had a shift of emphasis to problem-solving. Therefore, today 
scholars and educators take a cognitive approach that focuses on thinking abilities as the basis of creative work. Additionally, creativity as a concept has been used over time in a very broad sense. However, a fair definition of creative would be having the capacity to come up with "original, inventive and novel ideas" $[39, \mathrm{p}$. 6]. Creativity is also the foundation for innovation and discovery, which are characterized by the two qualities of usefulness and novelty [40].

\subsection{Literature review summary}

Therefore, the authors believe that PBL and teaching promote creativity, especially when implemented in the cloud using a constructivist learning environment. However, the process entails a variety of teaching concepts and theories which emphasize learners practicing and performing tasks from learning activities. Also, there is a variety of learning resources and approaches to problem-solving that differ according to interests which require behavior and thought development through a student-centered learning process. Learners can create works of knowledge, experiences, activities, or exchange knowledge with friends, teachers, experts, as well as cooperate between teachers and learners. Therefore, the following section details the methods, results, and discussion of the expert input and evolution of the study's models for use by Thai undergraduate students.

\subsection{Objectives of the research}

To develop and assess the appropriateness of a PBL and teaching model using a cloud-based constructivist learning environment (CBCLE) to enhance Thai undergraduate creative thinking and digital media skills.

\section{Method of model development and assessment}

This study used mixed research methods to develop a pattern [41] by combing elements of qualitative and quantitative research practices [42].

Initially, the qualitative research was reviewed, synthesized, and analyzed to produce a PBL learning model for creative and critical thinking enhancement using five primary steps. This was followed by a second qualitative analysis in which six steps were determined to be potentially useful in a blended learning environment. Finally, a quantitative analysis was conducted of the proposed model by a panel of seven experts.

\subsection{The proposed PPRPS model's five steps}

The PBL and teaching model using a cloud-based constructivist learning environment (CBCLE) to enhance Thai undergraduate creative thinking and digital media skills was determined to consist of five steps (Figure 1). These were (1) problem identification, (2), problem analysis, (3) research, (4) presentations, and (5) summary and evaluation. Therefore, the authors identified the initial proposed model as the "PPRPS Model". 


\section{Step 1: Problem identification}

The teacher plays a role in presenting the problem, issue, and case study related to the lesson to stimulate interest, from which teachers and students work together to define problems or issues that need to be solved. Groups are organized into $3-6$ students each based on assorted knowledge from the results of pre-study exams. Thereafter, learners collaborate in determining the problem or issue that needs to be solved and share the responsibility to find a solution within the group. Emphasis is placed on real roles such as group leader, data aggregator, and presenter through communication tools including Google Meet ${ }^{\circledR}$ and Line ${ }^{\circledR}$ social media platforms. Collaboration tools include Google Drive $^{\circledR}$, Google Docs ${ }^{\circledR}$, and Google Calendar ${ }^{\circledR}$. Therefore, participation in a co-learner community and on broader scale participation in a community of practitioners is characterized as socialization. This therefore can be extended into the broader social and cultural rules and conventions that are common to all global communities [43].

\section{Step 2: Problem analysis}

Students are given responsibility for analyzing, isolating, and discussing the root causes of the assigned problems to determine the issues or learning objectives, as well as conducting further research to gain more subject knowledge. The teacher's role is to introduce the learning environment and collaborative tools resources such as Google Drive $^{\circledR}$, Google Docs ${ }^{\circledR}$, and Google Calendar ${ }^{\circledR}$.

\section{Step 3: Research}

Each learner is responsible to research their new knowledge from the learning environment, including resources, cognitive tools, and support bases to bring the information to discuss, analyze, and synthesize per the objectives. During this process, a multitude of tools can be used to facilitate the five proposed steps. These include learning management systems (LMS) tools such as Google Classroom ${ }^{\circledR}$, Moodle ${ }^{\circledR}$, or Schoology ${ }^{\circledR}$, communication and social media tools such as Google Meet ${ }^{\circledR}$ and Line ${ }^{\circledR}$, collaboration tools such as Google Drive ${ }^{\circledR}$, Google Docs ${ }^{\circledR}$, Google Slides ${ }^{\circledR}$, and Google Calendar ${ }^{\circledR}$, and finally, creative tools such as Google Drawings ${ }^{\circledR}$ and Canva ${ }^{\circledR}$, among others.

\section{Stage 4: Presentations}

Numerous cloud-based products are also available to help students present their work including creativity tools such as Illustrator ${ }^{\circledR}$ Procreate $^{\circledR}$, Google Drawings ${ }^{\circledR}$ or Canva $^{\circledR}$, communication tools such as Google Meet ${ }^{\circledR}$, Google $e^{\circledR}$, and Line ${ }^{\circledR}$, and presentation tools such as Google Slides ${ }^{\circledR}$, YouTube ${ }^{\circledR}$, and PowToon ${ }^{\circledR}$. Students can make presentations through captions, pictures, or digital media. Instructors can create stimulating questions to show the relationship of the information to check the consistency of the work produced with the objectives.

\section{Step 5: Summary and evaluation}

In the final summary and evaluation process step learners come together to summarize new ideas or knowledge from the produced work. Although most would consider the above applications as productivity tools, in reality, these tools become a student's intellectual partner which enhances their cognitive powers during thinking, problem-solving, and learning [44], [45]. 
Finally, the teacher assesses the learning development of learners by assessing the results produced. The students assess themselves and assess the performance of the group members, which leads to the final post-test using learner assessment tools based on Google Form ${ }^{\circledR}$, Google Sheets ${ }^{\circledR}$, or Rubistar ${ }^{\circledR}$.

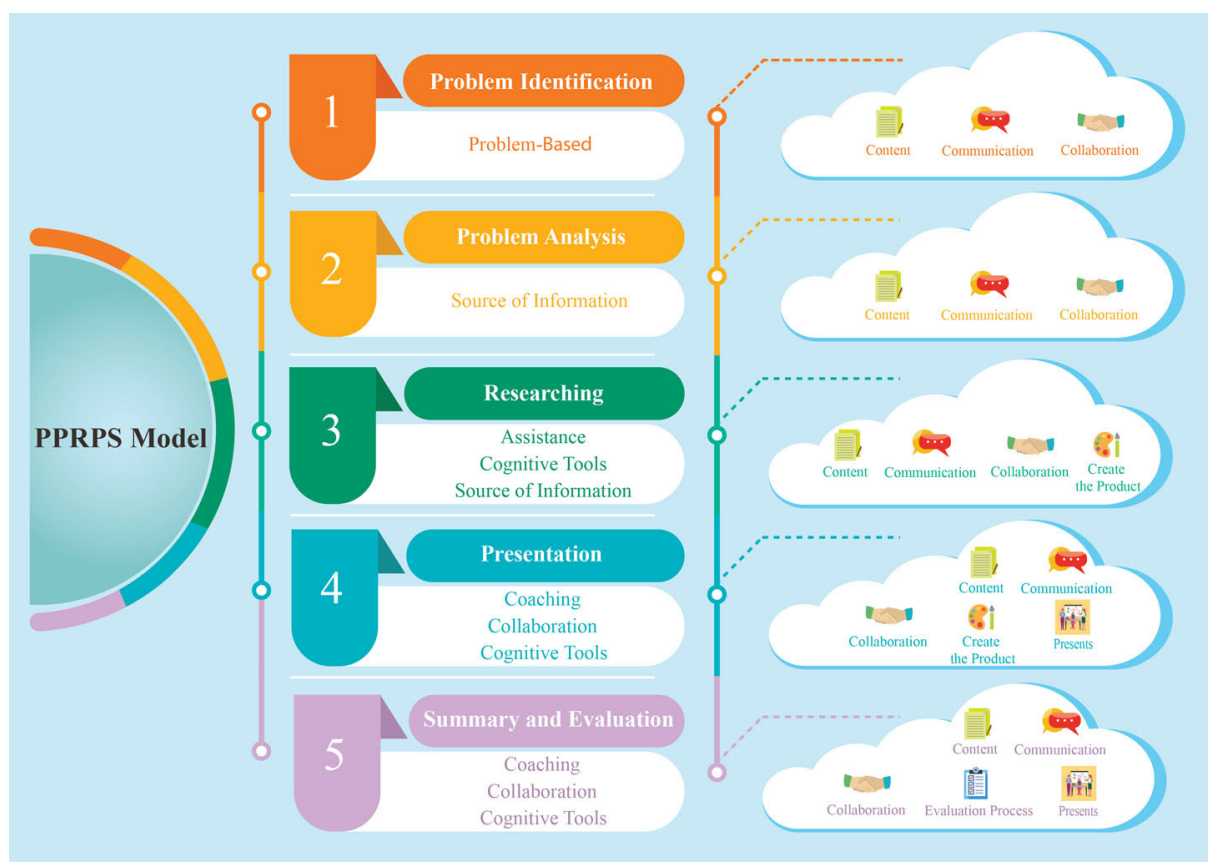

Fig. 1. The proposed PPRPS model

\subsection{PBL model's steps}

From the second phase of the qualitative analysis, the authors determined that six elements were important in a PBL model which utilized a cloud-based constructivist learning environment (CBCLE) to enhance Thai undergraduate creative thinking and digital media skills (Figure 2). These included (1) problem-based, (2) resources, (3) cognitive tools, (4) collaboration, (5) scaffolding, and finally, (6) coaching [35], [46].

\subsection{Experts' model assessment}

After the development of the study's initial proposed PPRPS Model, seven experts with PhDs were invited to assist with the assessment of the model. Each academic had expertise in some aspect of teaching-learning styles, innovation, creativity, computer education, technology, educational programs, or research. From the panel of experts' input, the researchers were asked to add to the model six learning environments (Figure 2). The final model's conceptual framework was consistent and well supported by research from other scholars in Thailand and around the world [35], [46], [47]. 


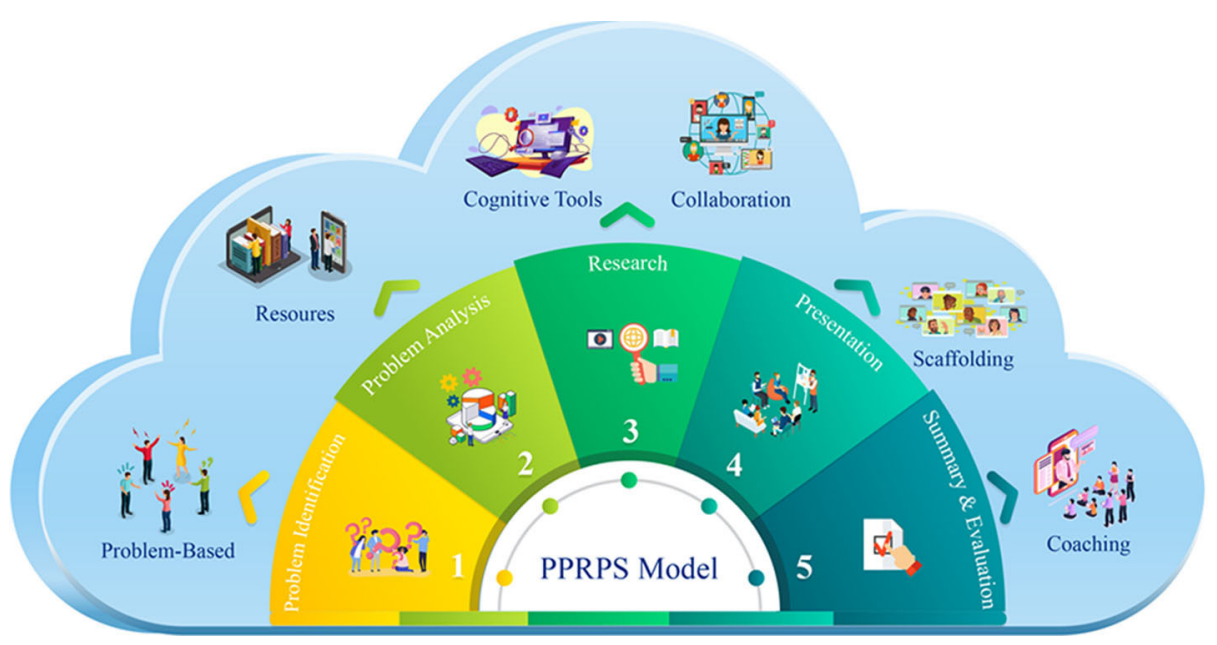

Fig. 2. The proposed PPRPS model in a CBCLE and the six related learning environments

\subsection{Experts' quantitative model assessment}

Finally, a 'suitability assessment form' was given to each of the seven experts to assess their opinions concerning the final model's overall suitability, benefits, feasibility, and accuracy [48]. Thereafter, descriptive analysis was undertaken on the five-level agreement scale using both the mean and standard deviation (S.D.).

\section{$4 \quad$ Results and discussion}

\subsection{Experts' descriptive analysis results from the final model's suitability assessment}

The descriptive analysis of the experts' opinions concerning the final model's overall suitability, benefits, feasibility, and accuracy was undertaken using both the mean and standard deviation (S.D.), with the model demonstrating excellent suitability according to the experts $($ Mean $=4.53$, S.D. $=0.50)($ Table 1$)$.

Table 1. Experts input concerning the PPRPS model's suitability assessment

\begin{tabular}{|l|c|c|l|}
\hline \multirow{2}{*}{\multicolumn{1}{|c|}{ Assessment Item }} & \multicolumn{2}{c|}{ Experts $(\boldsymbol{n}=\mathbf{7})$} & \multirow{2}{*}{ Suitability Level } \\
\cline { 2 - 3 } & Mean & S.D. & \\
\hline Suitability standard & 4.56 & 0.50 & Excellent suitability \\
\hline Benefits standard & 4.57 & 0.49 & Excellent suitability \\
\hline Feasibility standard & 4.49 & 0.50 & Appropriate suitability \\
\hline Accuracy standard & 4.48 & 0.50 & Appropriate suitability \\
\hline Total & 4.53 & 0.50 & Excellent suitability \\
\hline
\end{tabular}


The PBL and teaching model using a cloud-based constructivist learning environment (CBCLE) to enhance Thai undergraduate creative thinking and digital media skills was presented to a panel of seven experts from which the initial model was assessed. Thereafter, further dialog determined the need to add six learning environments to the model. These six learning environments were labeled (1) problem-based, (2) resources, (3) cognitive tools, (4) collaboration, (5) scaffolding, and finally, (6) coaching. These learning environments are also very similar to a study in which a CBCLE use for enhancing Thai undergraduate critical thinking skills included (1) problem base, (2) resources, (3) collaboration and coaching, (4) critical thinking lab, (5) scaffolding, and (6) cognitive tools [46]. Therefore, this allows learners to choose a learning environment that is most suitable for their problem situation. In addition, both students and teachers have cloud technology to help integrate and manage the various proposed learning environments.

\subsection{Problem-based environment}

In the study's revised final model design, both the assembled experts and supporting studies established the use of problem-based learning and teaching as the foundation and first step of the learning model for an effective CBCLE in enhancing Thai undergraduate creativity and digital media skills [35], [46].

\subsection{Resources environment}

Secondly, resources were determined to be the next key step in the process. Concerning this aspect of the model, the authors chose to define resources as 'digital' tools and platforms. As such, digital resources have limitations due to cost, location, availability, and user knowledge. Resources can entail a learner's smartphone, the teacher's LMS such as Schoology, the amount of Internet bandwidth, or availability to the cloudbased application such as Line.

This is consistent with similar studies in which constructivist learning environments were discussed and also defined resources as being based on the organization of information for multimedia design presentations [34]. Also, resources in another study were defined as a student's use of animation, visual and audio resources [35].

\subsection{Cognitive tools environment}

Thirdly, cognitive tools were determined to play a central role in the model's successful use and outcome with significant support coming from numerous scholars, old and new. A major reason today for this is the acceptance that application software is a tool that assists with the generation of cognitive skills such as problem-solving and critical thinking [44]-[46].

Moreover, databases and related applications can be thought of as MindTools which help learners integrate and interrelate discrete bits of content, making them more meaningful and more memorable [43]. By the use of these MindTools, learners engage in critical thinking and deeper thinking [49], [50]. In this situation, ICT applications are 
referred to as cognitive technologies [51], technologies of the mind [52], cognitive tools [44], [45] or MindTools [53], [54].

\subsection{Collaboration environment}

The next step within the proposed model is a collaboration which once again finds significant support in the global literature for successful student learning and creativity. This is consistent with research in the USA in which the authors stated that social media's ability to create opportunities for interaction allows the application of technology into social constructivist learning contexts in meaningful and innovative ways [55].

\subsection{Scaffolding environment}

Scaffolding was added to the final model by the panel of experts due to its importance in a mobile learning environment (MLE). This is supported by Vygotsky whose scaffolding concept describes how learners in a social context can be provided individualized and just enough help and guidance from its use [56]. This is consistent with studies in Turkey in which the researchers identified four significant elements of scaffolding in an MLE. These included the device type, provisioning source, implementation timing, and the strategies in which it is used [57]. It was also determined that an MLE increased student interest and motivation. Furthermore, from the four primary types of scaffolding identified (social, instructional, managerial, and technical) indicated in the study, participants most frequently used Facebook ${ }^{\circledR}$, then Twitter ${ }^{\circledR}$, Google Calendar ${ }^{\circledR}$ and Diigo ${ }^{\circledR}$ for social scaffolding. Twitter ${ }^{\circledR}$ and Google Calendar ${ }^{\circledR}$ were most often preferred for managerial scaffolding, while Diigo ${ }^{\circledR}$ was most often preferred for instructional scaffolding.

\subsection{Coaching environment}

Finally, collaboration, coaching, and cognitive tools are used for the collaborative learning process [43]. The concept of Cognitive Coaching ${ }^{\mathrm{SM}}$ is one that was initially developed for the support of teachers in which confidential, non-judgmental relationships between teachers and their coaches are established [58]. Thereafter, the relationship is based on authenticity, honesty, respect, and empathy, with each coach working to empower each teacher to be self-sufficient [59].

\section{Summary}

Therefore, according to UNESCO, when we examine contemporary constructivist learning, it is important to consider contemporary digital media [60]. Moreover, learning with mobile devices and their use in a PBL environment as a cognitive tool promotes higher-order thinking skills (HOTS) [38], [61].

In Thailand, it has been reported that one of the most important projects for educators is to develop student-centered approaches to learning. Thus, the outcome hoped for will be an elevation of student achievement, development of 21 st Century skills, and the 
encouragement of students to be good Thai citizens with good morals and ethics [37]. Furthermore in Thailand, the Office of the Basic Education Commission (OBEC) was tasked to assess achievement and propose new teaching and support methods including coaching, peer coaching, and mentoring [62].

Within these contexts, the study chose problem-based learning (PBL) and teaching as its foundation for the model, which is a learning process that works towards problem-understanding and problem-resolution [37]. Thus, educators should use problems to encourage students to explore knowledge and solve problems. PBL is a learner-centered pedagogical approach that allows learners to work collaboratively with others on complex problems. Learners are also taught how to work independently to find solutions to group problems [63], which inspires critical thinking, higher performance, good decision making, and the willingness to engage in teamwork.

Furthermore, other research has suggested that problem-based learning management (PBLM) is a process of design, implementation, and assessment steps [64] and suggest there are six steps in PBLM which include (1) Identify outcomes/assessments, (2) Design the scenario, (3) Introduce PBL, (4) Research, (5) Product performance, and finally, the (6) Assessment.

\section{Conclusion}

The study initially set out to determine which aspects had a significant potential impact on the development of a problem-based learning and teaching model which made use of a cloud-based constructivist learning environment (CBCLE) to enhance Thai undergraduate creative thinking and digital media skills. From this phase of the research, it was determined that five elements had the best fit. These included (1) problem identification, (2), problem analysis, (3) research information, (4) presentations, and (5) summary and evaluation. Thereafter, an analysis of the model was performed by a panel of seven experts who added that such a model should also include six additional learning environments. These learning environments included (1) problem-based, (2) resources, (3) cognitive tools, (4) collaboration, (5) scaffolding, and finally, (6) coaching. Finally, the final proposed learning model is well supported by similar studies globally. The study contributes to the literature as it details the tools educators should use in their learning environments to activate student learning creativity and enhance digital media skills.

\section{$7 \quad$ References}

[1] R. K. Kadambaevna, S. Bekchanqizi, R. L. Muminboevna, D. Z. Navfalqizi, A. S. Amatchonovna, and F. G. Erkinovna, "Implementing blended learning technology," Elementary Education Online, vol. 20, no. 5, 443-446, 2021. [Online serial]. Available: https:// doi.org/10.17051/ilkonline.2021.05.46 [Accessed Jun. 16, 2021]

[2] A. A. Almodaires, G. M. Alayyar, T. O. Almsaud, and F. M. Almutairi, "The effectiveness of flipped learning: A quasi-experimental study of the perceptions of Kuwaiti pre-service teachers," International Education Studies, vol. 12, no. 1, 10-23, 2018. [Online serial]. Available: https://doi.org/10.10.5539/ies.v12n1p10 [Accessed Jun. 16, 2021] 
[3] L. R. Kroll and V. K. Laboskey, "Practicing what we preach: Constructivism in a teacher education program," Action in Teacher Education, vol. 18, no. 2, 63-72, 1996. [Online serial]. Available: https://doi.org/10.1080/01626620.1996.10462834 [Accessed Jun. 16, 2021]

[4] M. Lodi and S. Martini, "Computational thinking, between Papert and Wing. Science \& Education," 2021. [Online serial]. Available: https://doi.org/10.1007/s11191-021-00202-5 [Accessed Jun. 16, 2021]

[5] J. Eppard and A. Rochdi, "A framework for flipped learning," in International Association for Development of the Information Society (IADIS) International Conference on Mobile Learning, 2017, https://tinyurl.com/5m7mb4ma [Accessed Jun. 16, 2021]

[6] A. Moto, T. Ratanaolarn, S. Tuntiwongwanich, and P. Pimdee, "A Thai junior high school students' 21 st Century information literacy, media literacy, and ICT literacy skills factor analysis. International Journal of Emerging Technologies in Learning," vol. 13, no. 9, 87-106, 2018, https://doi.org/10.3991/ijet.v13i09.8355 [Accessed Jun. 20, 2021]

[7] L. Wang, "Implementing and promoting blended learning in higher education institutions," in Comparative Blended Learning Practices and Environment, 2010, pp. 70-87, https://doi. org/10.4018/978-1-60566-852-9.ch004 [Accessed Jun. 16, 2021]

[8] Z. Zainuddin, H. D. Hermawan, F. Nuraini, S. M. Prayitno, and T. Probowasito, "Flipping the classroom with an LMS: Designing a technology-based learning model," Journal of Education and Learning, vol. 13, no. 3, 309-317, 2019. [Online serial]. Available: http:// dx.doi.org/10.11591/edulearn.v13i3.12886 [Accessed Jun. 16, 2021]

[9] K. Siripongdee, S. Tuntiwongwanich, and P. Pimdee, "Blended Learning Model with IoTbased by smartphone," International Journal of Interactive Mobile Technologies, vol. 15, no. 11, 166-182, 2021. [Online serial]. Available: https://doi.org/10.3991/ijim.v15i11.22441 [Accessed Jun. 20, 2021]

[10] L. Glowa and J. Goodell, Student-centered learning: Functional requirements for integrated systems to optimize learning. Vienna, Va.: International Association for K-12 Online Learning, 2016, https://tinyurl.com/ry9nr98u [Accessed Jun. 16, 2021]

[11] S. J. DeLozier and M. G. Rhodes, "Flipped classrooms: A review of key ideas and recommendations for practice," Educational Psychology Review, vol. 29, no. 1, 141-151, 2017. [Online serial]. Available: https://doi.org/10.1007/s10648-015-9356-9 [Accessed Jun. 20, 2021]

[12] D. McGrath, A. Groessler, E. Fink, C. Reidsema, and L. Kavanagh, "Technology in the flipped classroom," in The Flipped Classroom, Springer, 2017, pp. 37-56, https://doi. org/10.1007/978-981-10-3413-8_3 [Accessed Jun. 16, 2021]

[13] W. Baxter, Thailand 4.0 and the future of work in the Kingdom, International Labour Organization, 2017, http://tinyurl.com/mkhf5r5 [Accessed Jun. 16, 2021]

[14] S. S. Ali, "Problem based learning: A student-centered approach," English Language Teaching, vol. 12, no. 5, 73-78, 2019. [Online serial]. Available: https://doi.org/10.5539/elt. v12n5p73 [Accessed Jun. 16, 2021]

[15] K. Kruger, Higher-order thinking, Hidden Sparks, Inc., 2013.

[16] S. Handajani, H. Pratiwi, and Mardiyana, "The 21st century skills with model eliciting activities on linear program," Journal of Physics: Conference Series, vol. 1008, Article 012059, 2018. [Online serial]. Available: https://tinyurl.com/2hdk5a8 [Accessed Jun. 16, 2021]. https://doi.org/10.1088/1742-6596/1008/1/012059

[17] R. Chacón, H. Posada, A. Toledo, and M. Gouveia, "Development of IoT applications in civil engineering classrooms using mobile devices," Computer Applications in Engineering Education, vol. 26, no. 5, 1769-1781, 2018. [Online serial]. Available: https://doi.org/

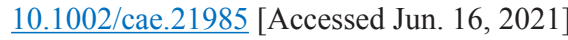

[18] G. Zurita and M. Nussbaum, "A constructivist mobile learning environment supported by a wireless handheld network," Journal of Computer Assisted Learning, vol. 20, no. 4, 
235-243, 2004. [Online serial]. Available: https://doi.org/10.1111/j.1365-2729.2004.00089.x [Accessed Jun. 16, 2021]

[19] U. Yakar, A. Sülü, and N. Çalış, "From constructivist educational technology to mobile constructivism: How mobile learning serves constructivism?" International Journal of Academic Research in Education, vol. 6, no. 1, 56-75, 2020. [Online serial]. Available: https://doi.org/10.17985/ijare.818487 [Accessed Jun. 16, 2021]

[20] W. Duangpummes and W. Kaewurai, "Learning management in Thailand 4.0 with active learning," Humanities and Social Sciences Journal of Pibulsongkram Rajabhat University, vol. 11, no. 2, 1-14, 2017. [Online serial]. Available: https://tinyurl.com/2jhzrbmt [Accessed Jun. 16, 2021]

[21] United Nations Children's Fund (UNICEF), Children in a digital world, 2017, https:// tinyurl.com/4zdzjsf6 [Accessed Jun. 16, 2021]

[22] A. K. Amin, I. N. D. Sudana, P. Setyosari, and E. T. Djatmika, "The Effectiveness of Mobile Blended Problem Based Learning on Mathematical Problem Solving," International Journal of Interactive Mobile Technologies, vol. 15, no. 1, 119-140, 2021. [Online serial]. Available: https://doi.org/10.3991/ijim.v15i01.17437 [Accessed Jun. 20, 2021]

[23] M. Leasa, A. D. Corebima, and J. R. Batlolona, "The effect of learning styles on the critical thinking skills in natural science learning of elementary school students," İlköğretim Online, 2086-2097, 2020. [Online serial]. Available: https://doi.org/10.17051/ilkonline.2020.763449 Actions [Accessed Jun. 16, 2021]

[24] R. I. Arends, Classroom instruction and management, McGraw-Hill, 1997.

[25] H. Suwono and E. K. Dewi, "Problem-based learning blended with online interaction to improve motivation, scientific communication and higher order thinking skills of high school students," in AIP Conference Proceedings, vol. 2081, 2019. [Online serial]. Available: https://doi.org/10.1063/1.5094001 [Accessed Jun. 16, 2021]

[26] D. Ammann, Y. Vignoli, and S. Kaap-Fröhlich, "How can problem-based learning be realised in blended learning format?", International Journal of Health Professionals, vol. 6, no. 1, 90-96, 2019. [Online serial]. Available: https://doi.org/10.2478/ijhp-2019-0010 [Accessed Jun. 16, 2021]

[27] L. T. Car, B. M. Kyaw, G. Dunleavy, N. A. Smart, M. Semwal, J. I. Rotgans, N. Low-Beer, and J. Campbell, "Digital problem-based learning in health professions: Systematic review and meta-analysis by the digital health education thank you sweetie collaboration," Journal of Medical Internet Research, vol. 21, no. 2, 1-12, 2019. [Online serial]. Available: https:// doi.org/10.2196/12945 [Accessed Jun. 16, 2021]

[28] W. Wahyudi, "The effectiveness of sharing blended project-based learning (SBPBL) model implementation in operating system course," International Journal of Emerging Technologies in Learning, vol. 15, no. 5, 202-211. [Online serial]. Available: https://doi. org/10.3991/ijet.v15i05.11266 [Accessed Jun. 20, 2021]

[29] N. S. Ismail, J. Harun, M. A. Z. M. Zakaria, and S. M. Salleh, "The effect of Mobile problem based learning application DicScience PBL on students' critical thinking," Thinking Skills and Creativity, vol. 28, 177-195, 2018. [Online serial]. Available: https://doi.org/10.1016/j. tsc.2018.04.002 [Accessed Jun. 16, 2021]

[30] E. H. J. Yew and K. Goh, "Problem-based learning: An overview of its process and impact on learning," Health Professions Education, vol. 2, no. 2, 75-79, 2016. [Online serial]. Available: https://doi.org/10.1016/j.hpe.2016.01.004 [Accessed Jun. 16, 2021]

[31] C. P. Dwyer, M. J. Hogan, and I. Stewart, "An integrated critical thinking framework for the 21st century," Thinking Skills and Creativity, vol. 12, 43-52, 2014. [Online serial]. Available: https://doi.org/10.1016/j.tsc.2013.12.004 [Accessed Jun. 16, 2021]

[32] E. H. J. Yew and H. G. Schmidt, "Evidence for constructive, self-regulatory, and collaborative processes in problem-based learning," Advances in Health Sciences Education, vol. 14, 
no. 2, 251-273, 2009. [Online serial]. Available: https://doi.org/10.1007/s10459-008-9105-7 [Accessed Jun. 16, 2021]

[33] D. M., Bressler, J. Oltman, and F. L. Vallera, "Inside, Outside, and Off-Site: Social Constructivism in Mobile Games," in Handbook of Research on Mobile Technology, Constructivism, and Meaningful Learning, J. Keengwe, ed., 2019, pp. 1-22, https://doi.org/10.4018/978-15225-3949-0 [Accessed Jun. 16, 2021]

[34] R. E. Mayer, The Cambridge handbook of multimedia learning. New York: Cambridge University Press, 2005. https://doi.org/10.1017/CBO9780511816819

[35] K. Deejring and S. Chaijaroen, "The Development of Constructivist Learning Environments. Model Enhancing Cognitive Flexibility for Higher Education," European Journal of Social Sciences, vol. 26, no. 3, 429-438, 2011. [Online serial]. Available: https://tinyurl. com/5vpc68r5 [Accessed Jun. 16, 2021]

[36] R. E. Yager, "The Constructivist Learning Model,” The Science Teacher, vol. 58, no. 6, 53-57, 1991.

[37] A. Surakarn, T. Junprasert, N. Chaiakkarakan, N. Peungposop, and R. Boonlop, "Active Learning and its Outcomes: A Case Study from the Education Reform Project in Thailand," The Journal of Behavioral Science, vol. 15, no. 1, 34-51, 2020. [Online serial]. Available: https://tinyurl.com/mrjvtyta [Accessed Jun. 16, 2021]

[38] O-S. Tan, Ed., Problem-based Learning and Creativity. Singapore: Centage, 2009.

[39] A. J. Cropley, More ways than one: Fostering creativity. Norwood, NJ: Ablex Publishing, 1992.

[40] R. J. Sternberg and T. Lubart, "Investing in creativity," Psychological Inquiry, vol. 4, no. 3, 229-232, 1993. [Online serial]. Available: https://doi.org/10.1207/s15327965pli0403 16 [Accessed Jun. 16, 2021]

[41] J. W. Creswell and V. L. P. Clark, Designing and conducting mixed methods research, Sage Publications, 2017.

[42] J. Schoonenboom and R. B. Johnson, "How to construct a mixed methods research design," KZfSS Kölner Zeitschrift für Soziologie und Sozialpsychologie, vol. 69, no. S2, 107-131, 2017. [Online serial]. Available: https://doi.org/10.1007/s11577-017-0454-1 [Accessed Jun. $16,2021]$

[43] P. A. Kirschner and G. Erkens, "Cognitive tools and mindtools for collaborative learning," Journal of Educational Computing Research, vol. 35, no. 2, 199-209, 2006. [Online serial]. Available: https://doi.org/10.2190/r783-230m-0052-g843 [Accessed Jun. 16, 2021]

[44] D. H. Jonassen and T. C. Reeves, "Learning with technology: Using computers as cognitive tools," in Handbook of research for educational communications and technology, D. H. Jonassen, ed., New York: Macmillan, 1996, pp. 693-719.

[45] S. P. Lajoie, ed., Computers as cognitive tools (Vol. 2): No more walls: Theory change, paradigm shifts, and their influence on the uses of computers for instructional purposes, Mahwah, NJ: Lawrence Erlbaum Associates, 2000.

[46] N. Loiypha and S. Chaijaroen, "The Framework for Development of ConstructivistWeb-Based Learning Environment Model to Enhance Mechanism and Critical Thinking for Undergraduate Students," Academic Services Journal Prince of Songkla University, vol. 29, no. 1,43-50, 2018. [Online serial]. Available: https://tinyurl.com/fbez9ahp [Accessed Jun. 20, 2021]

[47] D. Cunningham and T. Duffy, "Constructivism: Implications for the design and delivery of instruction," in Handbook of research for educational communications and technology, D. H. Jonassen, ed., New York: Macmillan, 1996, pp. 170-198, 1996.

[48] J. H. McMillan and S. Schumacher, Research in education: Evidence-based enquiry, New Jersey: Pearson Education, 2010. 
[49] A. S. Blignaut, The use of computer-based mindtools in teaching and learning. University of Pretoria, Department of Didactics, 1999.

[50] D. Jonassen and C. Carr, "Mindtools: Affording multiple knowledge representations for learning," in Computers as cognitive tools Volume II: No more walls, S. Lajoie, ed., New Jersey: Lawrence Erlbaum Inc., 2000, pp. 165-196. https://doi.org/10.1201/9781315045337-8

[51] R. D. Pea, "Beyond amplification: Using the computer to reorganize mental functioning," Educational Psychologist, vol. 20, no. 4, 167-182, 1985. [Online serial]. Available: https:// doi.org/10.1207/s15326985ep2004_2 [Accessed Jun. 16, 2021]

[52] G. Salomon, D. N. Perkins, and T. Globerson, "Partners in cognition: Extending human intelligence with intelligent technologies," Educational Researcher, vol. 20, no. 3, 2-9, 1991. [Online serial]. Available: https://doi.org/10.3102/0013189x020003002 [Accessed Jun. 20, 2021]

[53] D. H. Jonassen, Computers in the classroom: Mindtools for critical thinking, Columbus, OH: Merrill/Prentice-Hall, 1991.

[54] D. H. Jonassen, Computers as mindtools for schools: Engaging critical thinking, Upper Saddle River, NJ: Prentice-Hall, 2000.

[55] E. Yeh and N. Swinehart, "A Model for Mobile Social Media Integration in Constructivist ESL Classrooms," in Handbook of Research on Mobile Technology, Constructivism, and Meaningful Learning, J. Keengwe, ed., pp. 68-89, 2019, https://doi.org/10.4018/978-15225-3949-0 [Accessed Jun. 18, 2021]

[56] L. S. Vygotsky, Mind in society, Harvard University Press, 1978.

[57] O. Ozan, "Scaffolding in connectivist mobile learning environment," Turkish Online Journal of Distance Education, vol. 14, no. 2, Article 1, 2013. [Online serial]. Available: https://tinyurl.com/4f9639s7 [Accessed Jun. 18, 2021]

[58] A. L. Costa and R. J. Garmston, The Cognitive Coaching Seminars Foundation Training Learning Guide, Highlands Ranch, CO: Thinking Collaborative, 2012.

[59] W. T. Rogers, C. P. Hauserman, and J. Skytt, "Using Cognitive Coaching to Build School Leadership Capacity: A Case Study in Alberta," Canadian Journal of Education/Revue Canadienne de L'éducation, vol. 39, no. 3, 1-26, 2016. [Online serial]. Available: https://tinyurl. com/ct3npke9 [Accessed Jun. 18, 2021]

[60] United Nations Educational, Scientific and Cultural Organization, Information and communication technologies in teacher education: a planning guide. Paris, 2002, https://tinyurl. com/rktdrhxf [Accessed Jun. 18, 2021]

[61] D. Salim and A. Hamdani, "Mobile Learning: A Good Practice," Procedia-Social and Behavioral Sciences, vol. 103, 665-674, 2013. [Online serial]. Available: https://tinyurl. com/3skv2zps [Accessed Jun. 18, 2021]. https://doi.org/10.1016/j.sbspro.2013.10.386

[62] P. Cordingley and N. Buckler, "Mentoring and coaching for teachers' continuing professional development," in Mentoring and coaching in education, S. J. Fletcher and C. Mullen, eds., London: Sage Publications, 2012, pp. 215-227. https://doi.org/10.4135/9781446247549.n15

[63] C. D. Simone, "Problem-Based Learning in Teacher Education: Trajectories of Change," International Journal of Humanities and Social Science, vol. 4, no. 12, 17-29, 2014. [Online serial]. Available: https://tinyurl.com/y $77 \mathrm{mv} 245$ [Accessed Jun. 18, 2021]

[64] V. R. Genareo and R. Lyons, "Problem-Based Learning: Six Steps to Design, Implement, and Assess," Faculty Focus, 30 November, 2015, https://tinyurl.com/snxhsxc5 [Accessed Jun. 16, 2021] 


\section{Authors}

Parawee Srikan is a doctoral student in the Computer Education Program, Faculty of Industrial Education and Technology, King Mongkut Institute of Technology Ladkrabang (KMITL), Bangkok, Thailand. Her research focuses on problem-based constructivist learning environments, cloud computing, and creative thinking.

Paitoon Pimdee is an Associate Professor with the Faculty of Industrial Education and Technology at the King Mongkut's Institute of Technology Ladkrabang (KMITL) in Bangkok, Thailand. He graduated with a Bachelor of Arts in Economics and a Master of Science (M.Sc.) degree in science education. He also holds a Ph.D. in environmental education and behavioral sciences and specializes in environmental issues, energy conservation, and ecotourism.

Punnee Leekitchwatana is an Associate Professor in the Faculty of Industrial Education and Technology at the King Mongkut's Institute of Technology Ladkrabang (KMITL) in Bangkok, Thailand. She graduated with a B.Ed. and M.Ed. in science education and has an Ed.D. in curriculum research and development. She specializes in educational research, science education, curriculum development, and measurement/ evaluation in education.

Akan Narabin is an Assistant Professor with the Faculty of Science at the King Mongkut's Institute of Technology Ladkrabang (KMITL) in Bangkok, Thailand. He graduated with a B.Sc., M.Sc., and Ph.D. degree in Computer Science. He specializes in computer programming, application software, and object-oriented programming.

Article submitted 2021-06-20. Resubmitted 2021-07-05. Final acceptance 2021-07-06. Final version published as submitted by the authors. 